\title{
Retrospective Analysis of the Clinical Presentation of Progressive Macular Hypomelanosis and Outcome of Its Therapeutic Intervention with Narrow- Band Ultraviolet B Phototherapy
}

\author{
Ukonu, Bob A (FMCP, MBBS) ${ }^{1}$, Ibekwe, Perpetua U.(PhD, FMCP,MBBS) ${ }^{2}$, \\ Otokpa,Grace A.(MBBS) ${ }^{3}$ \\ ${ }^{1,2,3}$ Dermatology Unit, Dept. Of Medicine, University Of Abuja Teaching Hospital, Gwagwalada Abuja
}

\begin{abstract}
Progressive Macular Hypomelanosis is often an underdiagnosed hypo pigmented, nonscaly, macular eruption involving the trunk, abdomen, face,extremities and the buttocks with great cosmetic concern to the sufferer. Topical antifungal, corticosteroid has been ineffective in its treatment but phototherapy and topical antimicrobial has proven effective over time.

Objective: This study seeks to determine the clinical presentation of Progressive Macular Hypomelanosis in our environment and its response to Narrowband-Ultraviolet $B(N B-U V B)$

Methods: Twenty-three patients who were diagnosed as having Progressive Macular Hypomelanosis and had $N B-U V B$ exposure were retrieved from dermatology unit records. Their pattern of presentation and their treatment outcome analyzed

Result: The mean age $(S D)$ of the study population was $28.0( \pm 13.6)$ years ranging from 7-55 years. Male to female ratio was 3.6: 1. The percentage body surface area covered ranged from 3-60\% and areas most affected included the face, trunk, extremities, buttocks and scalp respectively. Significant repigmentation was noticed at 12 th sessions of $N B-U V B$ exposure and with almost maximum restoration at 18 sessions of exposure. However, there was a relapse in 4 patients at 4- 12 months of stoppage of NB-UVB.

Conclusion: Progressive Macular Hypomelanosis seemed to be more generalized in much younger age group when compare with older adults and NB-UVB exposure was helpful in their treatment.
\end{abstract}

Keywords: Progressive Macular Hypomelanosis, clinical presentation, NB-UVB'

\section{Introduction}

Progressive macular hypomelanosis (PMH) was originally described in patients with FitzPatrick's skin type IV-VI from tropical and subtropical countries of the world $(1,2)$. However, it has been found to have a world-wide distribution (2). The precise aetiology and pathogenesis of PMH is yet to be fully understood. Although, Westerhof et al had observed that hair follicles within the lesions fluoresce coral red under wood lamp, but not inter-follicular or non-lesional skin (3). This suggests the presence of a porphyrin producing organism in the follicle, of which they were able to isolate and identify as gram positive nonspore- forming anaerobic rod propronibacterium acnes $(3,4)$. PMH is a common, often misdiagnosed dermatosis with a great cosmetic concern to the sufferer. Presentation is asymptomatic, ill-defined to discoid, non-scaly, symmetrical hypopigmented macules that sometimes coalesce into patches $(4,5)$. The eruptions are often seen on the trunk, face and a satellite extension to the extremities, neck and buttocks. $(4,5,6)$. The clinical course of the lesions varies and some authors have asserted that the lesions tend to stabilize and undergo spontaneous regression over a period of 2-5years (2). While others stated that the normal course is one of a slow progression of the lesion overtime (6). Some researchers have also reported more female preponderance in the ratio $3: 1$ when compared with male gender, but other studies did not support this observation $(3,5-9)$. PMH can easily be distinguished from other hypopigmented disorder such as pityriasis alba, pityriasis versicolor, mycosis fungoides, vitiligo, leprosy and postinflammatory hypopigmentation both clinically and histologically $(1,5)$. For example, it is not associated with initial erythema and scaling of pityriasis alba. In PMH, there is normal sensation, no prior history of inflammation, trauma, itching, pain or infection. Potassium hydroxide mounts of skin scrapings for Malassezia fungi is negative. Histologically, PMH is characterized by diminished pigment in the epidermis and a normal looking dermis $(5,6)$. Presently, there is no agreeable first line treatment for Progressive Macular Hypomelanosis after trials of many treatment options (3).

Phototherapy alone has been attempted for the treatment of PMH with variable outcomes. Psoralen ultraviolet A (PUVA) therapy was noticed to induce repigmentation after six (6) weeks of therapy but hypopigmented spots recurred in the same location within few weeks of stopping PUVA (10). Also, an uncontrolled prospective study of narrowband ultraviolet B (NB-UVB) therapy was performed on 17 patients and repigmentation occurred by a gradual darkening of the lesions after some sessions of exposure. This was in contrast to repigmentation observed in vitiligo which occurred from discrete perifollicular islands $(7,11)$. The 
speculative mode of action for the efficacy of NB-UVB phototherapy includes stimulation of melanogenesis and antimicrobial effects $(7,12)$. This study aims to define the clinical course of progressive macular hypomelanosis and its possible therapeutic outcome with NB-UVB $(311 \mathrm{~nm})$ in our environment.

\section{Objectives}

The aim of this paper is to determine the clinical presentation of progressive macular hypomelanosis in our environment and its response to narrowband-ultraviolet B (NB-UVB)

\section{Materials And Methods}

This was a retrospective study involving patients who were seen in our dermatology outpatients clinic from December 2013 to November 2016 in University of Abuja Teaching Hospital. Out of one thousand four hundred and four (1404) new patients seen, twenty three (23) of them were diagnosed as having progressive macular hypomelanosis, clinically and histologically where necessary. A questionnaire was designed to capture the following: bio data, body mass index (BMI), other family members with similar disease, clinical distribution of the lesion, duration of lesion, medication on or before presentation, minimal erythema dose (MED) at the commencement of narrow-band phototherapy (NB-UVB), number of sessions before noticeable repigmentation, percentage of repigmentation, relapse of repigmentation after stoppage of NB-UVB phototherapy, any adjunctive medication while on phototherapy and any noticeable side effect(s).

Patients who had progressive macular hypomelanosis were exposed to narrow-band ultraviolet B $(311 \mathrm{~nm})$ after explanation and consent duly signed for exposure. The NV-UVB $(311 \mathrm{~nm})$ used was a Philip TL 01 (1000 series) ultraviolet therapy lamp unit with 8 bulbs by Solarc system incorporated (13). TL/W/01 is a panel with eight (8) fluorescent bulbs protected with a wire guard. Each of those bulbs delivers irradiant energy at the rate of $6.5 \mathrm{mw} / \mathrm{cm}^{2}$

Irradiance $=\underline{\text { Expose Dose }\left(1 \mathrm{joule} / \mathrm{cm}^{2}\right)}$

Exposure time (seconds)

Acceptable distance or positioning at the commencement of treatment was 8inches-12inches $(20-30 \mathrm{~cm})$ and energy delivered can vary due to time exposure $(13,14)$. A minimal erythema dose (MED) was obtained for each patient as minimal energy delivered to cause mild redness on the skin of the patient after 24hours. However, because of the difficulty in obtaining MED in black skin an alternative which depends on skin type, previously described was used $(14,15,16,17)$

\begin{tabular}{lll}
\hline Skin type & Dose $\left(\mathbf{m j} / \mathbf{c m}^{\mathbf{2}}\right)$ & Time (seonds) \\
\hline I & 300 & 45 \\
II & 400 & 60 \\
III & 600 & 90 \\
IV & 800 & 120 \\
V & 1000 & 150 \\
VI & 1500 & 225 \\
\hline
\end{tabular}

Almost all the patients were of the skin type V or VI, thus, their alternative MED were set at 1000 joules $/ \mathrm{cm}^{2}$ and above.Time of exposures or energy delivered was increasingly done at the rate of $20 \%$ to $25 \%$ of the previous energy exposed or with recourse to any observable side effect. Each patient had a chart where progress of their treatment, total energy delivered (TED) per session per week and side effect were duly documented. Other precautionary measures taken include wearing of opaque goggles during treatment and boxers for male patients during whole-body exposure. Progress of treatment was assessed based on skin colour restoration. Those who had no colour change scored $0-25 \%$, minimal skin colour restoration were scored $26 \%$ $49 \%$, moderate skin colour restoration were scored 50\%-70\% and maximum skin colouration were scored 76\%99\% and complete repigmentation score was 100\%. The information retrieved was into SPSS 20 and analysed accordingly. Frequency, means, standard deviation and correlations were some of the statistical tools used.

\section{Result}

A total number of 23 patients with PMB were recruited into the study. Mean age (standard deviation) was 28.0 (13.6) years and ranged -7-55 years. Male to female ratio was 3.6:1. Body surface area covered (in \%) ranged 3-60\% with a mean of $18.6 \%$. Seven 7 (30.4\%) declined treatment while $16(69.9 \%)$ were treated with NB-UVB. Out of the 16, repigmentation was noticed in 13 (81.3\%) cases. However, 4 cases of relapse were observed after 4-12 months of follow up. Up to $25 \%-90 \%$ repigmentation was noticed between 9 to $\geq 18$ sessions. Mean (SD) MED was 1762.5 (552.4)joules $/ \mathrm{cm}^{2}$, ranged 1000-2400joules $/ \mathrm{cm}^{2}$. Number of sessionswas 6-49times with mean of 14.3 sessions.The duration of disease before presentation was $1.5-12$ years with a mean duration of 5.2years. 
Body surface area mostly affected was the face. While, 20 patients had hypopigmentation both on the face and other parts of the body, three had hypopigmentation on the face alone. Other parts of the body affected alongside the face include, the trunk, upper and lower limb, scalp, and buttocks. The part of the face mostly affected was the malar area and the nose (Table 1).

Table 1: Demographic characteristics and body surface area covered

\begin{tabular}{|c|c|c|}
\hline Variables & $\begin{array}{l}\mathrm{N}=23 \\
\text { Frequency }\end{array}$ & $\begin{array}{l}100 \% \\
\text { Percent }(\%)\end{array}$ \\
\hline \multicolumn{3}{|l|}{ Age group (years) } \\
\hline$\square$ 15years & 6 & 26.1 \\
\hline$>15$ years & 17 & 73.9 \\
\hline \multicolumn{3}{|l|}{ Sex } \\
\hline Male & 18 & 78.3 \\
\hline Female & 5 & 21.7 \\
\hline \multicolumn{3}{|l|}{ Education Status } \\
\hline Primary & 6 & 26.1 \\
\hline Secondary & 5 & 21.7 \\
\hline Tertiary & 12 & 52.2 \\
\hline \multicolumn{3}{|l|}{ Treatment } \\
\hline No treatment & 7 & 30.4 \\
\hline Treatment & 16 & 69.6 \\
\hline \multicolumn{3}{|l|}{ Body surface area covered } \\
\hline Face, Trunk and Upper Limb & 11 & 47.8 \\
\hline Face and Trunk & 4 & 17.4 \\
\hline Face & 3 & 13.0 \\
\hline Face, Trunk and Scalp & 2 & 8.7 \\
\hline Face and Thigh & 1 & 4.3 \\
\hline Face, Trunk, Upper limb and buttocks & 1 & 4.3 \\
\hline Buttocks and extremities & 1 & 4.3 \\
\hline
\end{tabular}

$\mathrm{N}=$ Total number of patients with $\mathrm{PMH}$

Face $($ Malar $=4$, nose $=3$, forehead $=1$, chin=1)

There were $18(78.3 \%)$ males and $5(21.7 \%)$ females. Six $6(26.1 \%)$ were aged $\leq 15 y e a r s$ and 17 $(73.9 \%)$ were older than 15years. Those who had primary education were $6(26.1 \%), 5(21.7 \%)$ and $12(52.2 \%)$ had secondary and tertiary education respectively. The number of patients treated were $16(69.6 \%)$ while 7 $(30.4 \%)$ declined treatment. Eleven $11(47.8 \%)$ of the patients had hypopigmentation on the face, trunk and upper limb, 4 (17.4\%) of them had hypopigmentation on the face and trunk only while $3(13.0 \%)$ of the patients had hypomelanosis on the face only(Table 1).

Table 2: Relationship between Body surface area involvement of the lesions and age

\begin{tabular}{llll}
\hline Age (years) & Mean BSA \pm SD & t & P \\
\hline$\square$ 15years & $35.3 \pm 23.5$ & 3.208 & $0.004^{* *}$ \\
$>$ 15 years & $13.8 \pm 9.4$ & & \\
& & & \\
Parameter & Mean \pm SD & Rho & $\mathbf{P}$ \\
Age (years) & $28.0 \pm 13.6$ & 1 & $0.031^{* *}$ \\
BSA $(\%)$ & $19.4 \pm 16.8$ & -0.451 & \\
\hline
\end{tabular}

**Statistically significant $(\mathbf{p}<\mathbf{0 . 0 5})$

Mean BSA (\%) involvement of the lesions in patients with ages $\leq 15$ years was $35.3 \%$. This was significantly higher than was observed in patients older than15years (mean BSA of 13.8) at $\mathrm{p}=0.004$. There was a negative moderate correlation between age and percentage BSA. This indicates that as the ages increased, the body surface area involvedwith PMH is reduced and this relationship was statistically significant $(\mathrm{p}=0.031)$. 
Retrospective Analysis Of The Clinical Presentation Of Progressive Macular Hypomelanosi....

Table 3: Relationship between number of sessions and other variables

\begin{tabular}{|c|c|c|c|}
\hline & Rho & $\mathbf{P}$ & Decision \\
\hline Number of session & 1 & - & - \\
\hline Age & -0.017 & 0.939 & Not significant \\
\hline Body mass index & -0.034 & 0.877 & Not significant \\
\hline Duration of disease & -0.282 & 0.192 & Not significant \\
\hline $\begin{array}{l}\text { Minimal Erytherma } \\
\text { Dose }\end{array}$ & 0.650 & 0.001 & Highly significant \\
\hline Total TED & 0.866 & $<0.0001$ & Highly significant \\
\hline $\begin{array}{l}\text { Body surface area } \\
\text { covered }(\%)\end{array}$ & -0.001 & 0.996 & Not significant \\
\hline $\begin{array}{l}\text { No of weeks on } \\
\text { treatment }\end{array}$ & 0.819 & $<0.0001$ & Highly significant \\
\hline Repigmentation & 0.617 & 0.001 & Highly significant \\
\hline
\end{tabular}

TED- Total Energy delivered

There was strong a correlation between number of session and minimal erythermal dose, total energy delivered, number of weeks on treatment and repigmentation (Table 3). These relationships were highly significant $(\mathrm{p}<0.05)$. The summary of Patients' treatment outcome is documented on table 4. Repigmentation was noticed between $9^{\text {th }}$ sessions and $18^{\text {th }}$ sessions of narrowband UVB phototherapy.

Table 4: Outcome of Treatment Response of progressive macular hypomelanosis and NB-UVB phototherapy

\begin{tabular}{|c|c|c|c|c|}
\hline $\begin{array}{l}\text { Total No. } \\
\text { of } \\
\text { sessions }\end{array}$ & $\begin{array}{l}\text { TED } \\
\text { In } \mathbf{J} / \mathrm{cm}^{2} \\
\end{array}$ & $\%$ Repigmentation & Relapse & Age (years) \\
\hline 18 & 53200 & $\begin{array}{l}60-70 \% \text { Repigmentation noticed on } \\
\text { the face and trunk at } 12 \text { sessions. At } \\
\text { the } 18 \text { sessions, up to } 70-90 \% \\
\text { repigmentation noticed on the face } \\
\text { and trunk and } 40-60 \% \text { noticed on the } \\
\text { buttocks }\end{array}$ & $\begin{array}{l}\text { No relapse after } 10 \text { months } \\
\text { of follow up }\end{array}$ & $\leq 15$ years \\
\hline 18 & 55800 & $\begin{array}{l}\text { Repigmentation noticed on the face } \\
\text { at the } 9 \text { sessions and at the } 18 \\
\text { sessions, up to } 70-80 \% \\
\text { repigmentation was noticed on the } \\
\text { face, trunk and extremiites }\end{array}$ & $\begin{array}{l}10 \% \text { relapse noticed after } \\
6 \text { months of follow up }\end{array}$ & $\leq 15$ years \\
\hline 12 & 24700 & $\begin{array}{l}\text { Up to } 40-50 \% \text { repigmentation } \\
\text { noticed on the face at the } 9 \text { sessions }\end{array}$ & $\begin{array}{l}\text { No relapse after } 6 \text { months } \\
\text { of follow up }\end{array}$ & $\leq 15$ years \\
\hline 9 & 27200 & $\begin{array}{l}\text { No observable repigmentation } \\
\text { noticed }\end{array}$ & Loss to follow up & $\leq 15$ years \\
\hline 15 & 49600 & $\begin{array}{l}80 \% \text { repigmentation noticed on the } \\
12 \text { sessions and } 90 \% \text { repigmentation } \\
\text { noticed at the buttocks and upper } \\
\text { limb }\end{array}$ & $\begin{array}{l}\text { No relapse after } 7 \text { months } \\
\text { of follow up }\end{array}$ & $>15$ years \\
\hline 6 & 10100 & $\begin{array}{l}\text { No observable repigmentation } \\
\text { noticed }\end{array}$ & Loss to follow up & $\leq 15$ years \\
\hline 9 & 24480 & $\begin{array}{l}40-60 \% \text { repigmentation noticed on } \\
\text { the face at the } 9 \text { sessions }\end{array}$ & $\begin{array}{l}\text { No relapse after } 10 \text { months } \\
\text { of follow up }\end{array}$ & $>15$ years \\
\hline 15 & 47200 & $\begin{array}{l}40-60 \% \text { repigmentation noticed on } \\
\text { the face and } 20-40 \% \text { repigmentation } \\
\text { noticed on the trunk at the } 12 \\
\text { sessions }\end{array}$ & $\begin{array}{l}\text { Noticed relapse after } 4 \\
\text { months of follow up }\end{array}$ & $>15$ years \\
\hline 15 & 47200 & $\begin{array}{l}60 \% \text { and } 80 \% \text { repigmentation } \\
\text { noticed on the face at the } 12 \text { sessions } \\
\text { and } 15 \text { session respectively }\end{array}$ & $\begin{array}{l}\text { Noticed relapse after } 8 \\
\text { months of follow up }\end{array}$ & $>15$ years \\
\hline 9 & 24000 & $\begin{array}{l}25 \% \text { repigmentation noticed on the } \\
\text { face at the } 9 \text { sessions }\end{array}$ & $\begin{array}{l}\text { No relapse after } 8 \text { months } \\
\text { of follow up }\end{array}$ & $>15$ years \\
\hline
\end{tabular}




\begin{tabular}{|c|c|c|c|c|}
\hline 12 & 35200 & $\begin{array}{l}40 \% \text { repigmentation noticed on the } \\
12 \text { sessions }\end{array}$ & $\begin{array}{l}\text { No relapse after } 7 \text { months } \\
\text { of follow up }\end{array}$ & $>15$ years \\
\hline 16 & 52600 & $\begin{array}{l}40 \% \text { and } 50 \% \text { repigmentation } \\
\text { noticed on the face and posterior } \\
\text { trunk at the } 12 \text { sessions and } 15 \\
\text { session respectively }\end{array}$ & $\begin{array}{l}\text { Nil relapse } \\
\text { repigmented skin }\end{array}$ & $>15$ years \\
\hline 49 & 67800 & $\begin{array}{l}40 \% \text { and } 50 \% \text { repigmentation } \\
\text { noticed on the face at the } 15 \text { sessions } \\
\text { and } 18 \text { session respectively }\end{array}$ & $\begin{array}{l}\text { Relapsed repigmentation } \\
\text { on the face }\end{array}$ & $>15$ years \\
\hline 6 & 12800 & $\begin{array}{l}\text { No observable repigmentation } \\
\text { noticed }\end{array}$ & Loss to follow up & $>15$ years \\
\hline 9 & 23400 & $\begin{array}{l}\text { Up to } 25 \% \text { repigmentation noticed } \\
\text { on the face at } 9 \text { sessions }\end{array}$ & $\begin{array}{l}\text { No relapse after } 6 \text { months } \\
\text { of follow up }\end{array}$ & $>15$ years \\
\hline 10 & 13400 & $\begin{array}{l}\text { Up to } 35 \% \text { repigmentation noticed } \\
\text { on the face and trunk at } 9 \text { sessions }\end{array}$ & $\begin{array}{l}\text { No relapse after } 7 \text { months } \\
\text { of follow up }\end{array}$ & $\leq 15$ years \\
\hline
\end{tabular}

Age- Patients'age as at the start of the study; TED-Total Energy Delivered
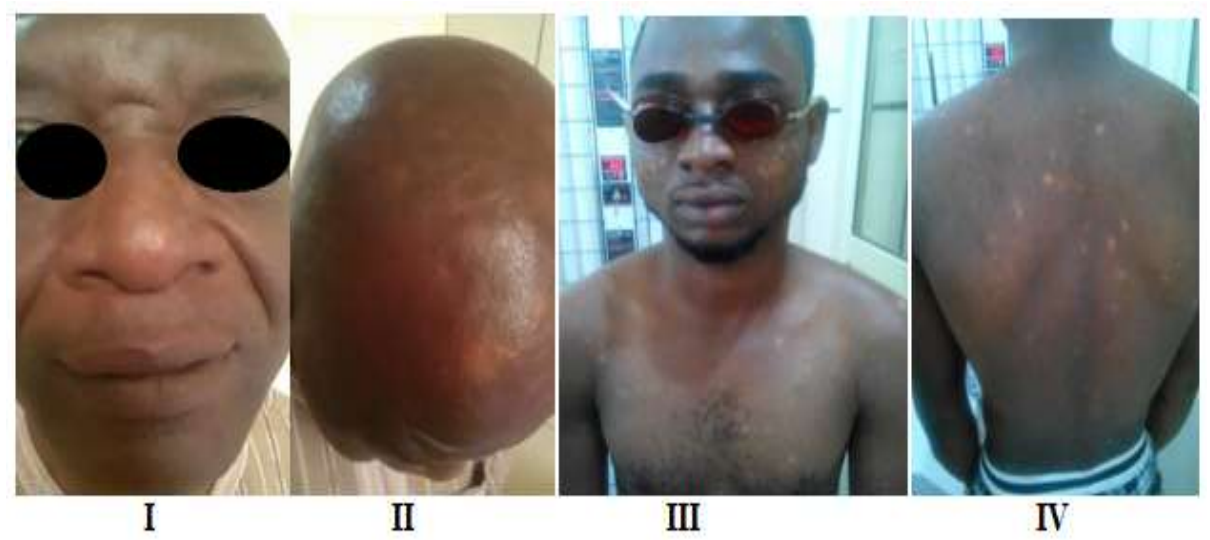

Figure I, II, III, IV respectively shows different clinical presentations of PMH

\section{Discussion}

Progressive macular hypomelanosis is a rarely diagnosed disorder which poses challenges in relevant differential diagnosis of hypopigmentations.(1) Guillet etal had described the disorder as a primary, acquired, non-scaly macular hypopigmentation affecting mainly women from 18 years to 25 years of age (1). Young women of West Indies extract and Caribbean immigrant population in France were seen having a widespread hypochromic macules on the trunk and less frequently on the abdomen $(1,2)$.

In this study, there was predominance of male patients $(78.3 \%)$ when compared with females. This is in agreement with Martinique et al who revealed that the disease is more widespread in men than women with mean age of 25 years (18). Other studies have shown that progressive macular hypomelanosis can occur on any skin type but more frequently on Fitpatrick skin type IV- VI $(2,3,5)$ and this was consistent with our findings. More than $90 \%$ of our patients had presentation of lesion on the face (mostly on the malar area, the nose, the forehead and the chin respectively). Other researchers had reported more of the lesions occurring on the trunk and the abdomen with rare involvement of the face and extremities $(1,2,3,6)$. We found more percentage body surface area involvement in patients below 20 years when compared with older adults 30 years and above. About $12(52.2 \%)$ of the patients who were 30 years and above have had the lesions present for more than 5 years without any sign of clinical improvement. This was in contrast with earlier observation by previous researchers $(4,12,19)$.

There have been variable outcomes of repigmentations in patients that have PMH who were exposed to narrowband ultraviolet B (NB-UVB). Duarte et al and Kim with his co researchers had reported more than 50\% clinical improvement at the 16th session of NB-UVB $(7,20)$. In the same study $39 \%$ had their lesion completely cured, while $26 \%$ had clinical improvement of their conditions up to $80-90 \%$ (20). Our findings showed upto $50 \%$ of our patients on NB-UVB had about $60 \%$ of their skin colour restored by 12 sessions of exposure while 
those who had NB-UVB exposure for onand above 18 sessions achieved more than $75 \%$ maximum skin colour restoration. Although, 4 patients had a relapse of their repigmentation at 4-12 months after stoppage of NBUVB exposure, response to NB-UVB were noticed to improve speedily from face, trunk, upper limbs, buttocks and lower limbs in that order. Notably, lesions on the scalp were noticed to have not responded to NB-UVB phototherapy.

\section{Conclusion}

In conclusion, this study has helped to highlight the fact that $\mathrm{PMH}$ is an emerging cosmetic embarrassing disorder in our environment. It is more generalized when it appears in much younger age group as compared with older adult. NV-UVB is helpful when a reasonable number of sessions of exposure are done and maintenance dose needful to avoid relapse of repigmentation.

\section{References}

[1]. Guillet G, Hélénon R, Gauthier Y, Surleve-Bazeille JE, Plantin P, Sassolas B. Progressive macular hypomelanosis of the trunk: Primary acquired hypopigmentation. J. Cutaneous Pathol 1988; 15: 286-289

[2]. Lesueur A, Garcia-Granel V, Helenon R, Cales-Quist D. Progressive macular confluent hypomelanosis in mixed ethnic melanodermic subjects: An epidemiologic study of 511 patients. Ann Dermatol Venereol. 1994; 121: 880-883

[3]. Westerhof W, Relyveld GN, Kingswijk MM, de Man P, Menke HE. Propionibacterium acnes and the pathogenesis of Progressive macular hypomelanosis. Arch Dermatol, 2004; 140: 2010-2014

[4]. Relyveld GN, Menke HE, Westerhorf W. Progressive macular hypomelanosis: An overview. Ann J. clinical Dermatol 2007; 8: 1319

[5]. Desai SR, Owen JL. Progressive macular hypomelanosis: An update. Pigment Int 2014; 1:52-55

[6]. Martinez-Martinez ML, Azana-Defez JM, Rodriguez-Vazquez M, Faura-Beruga C, Escario-Travesedo E. Progressive macular hypomelanosis. Pediatr Dermatol 2012; 29:460-462

[7]. Kim MB, Kim GW, Cho HH, Park HJ, Kim HS, Kim SH, et al. Narrowband UVB treatment of Progressive macular hypomelanosis. J. Am Acad Dermatol 2012; 66: 598-605

[8]. Elmariah SB, Kundu RV. Progressive macular hypomelanosis. J Drugs Dermatol 2011; 10: 502-506

[9]. Santos JB, Almeida OL, Silva LM, Barrero ER. Efficacy of topical combination of benzoyl perioxide 5\% and clindamycin $1 \%$ for the treatment of Progressive macular hypomelanosis: A randomized, double blind placebo-controlled trial. A Bras Dermatol 2011; 86:50-54

[10]. Menke H, Relyveld G, Westerhof W. Comment on the letter by Chung et al about Progressive macular hypomelanosis, J Eur Acad Dermatol Venerol 2008; 22:1029-1030

[11]. Fluhr JW, Gloor M. The antimicrobial effect of narrow-band UVB (345-440nm) radiation in vitro. Photodermatolo Photoimmunol Photomed, 1997; 13:197-201

[12]. Chung YL, Goo B, Chung WS. A case of Progressive macular hypomelanosis with narrow-band UVB. J. Eur Acad Dermatol Venereol 2007; 21:1007-1009

[13]. Van Weelden H, Baart De La Faillel H, Young E, van der Leun JC. A new development in UVB phototherapy of Psoriasis. B. Journal of Dermatology, 1988; 119 (1): 11-19

[14]. Karvonen J, Kokkonen E-L, Ruotsalainen E. 311nm UVB lamps in the treatment of Psoriasis with the Ingram regimeN. Acta Derm Venereol (Stockh) 1989; 69:82-85

[15]. Gordon PM, Saunders PJ, Diffey BL, Farr PM. Photo testing prior to narrowband (TL-01) Ultraviolet B phototherapy. Br J Dermatol 1988; 139:811-814

[16]. Das S, Lloyd JJ, Farr PM. Similar dose-response and persistence of erythema with broad-band and narrow-band ultraviolet B lamps. J invest Dermatol 2001; 117: 1318-1321

[17]. Gloor M, Scherotzke A. Age dependence of ultraviolet light-induced erythema following narrow-band UVB exposure. Photodermatol Photoimmunol Photomed 2002; 18:121-126

[18]. Gullet G and Gulliet MH. Creole dyschromia or idiopathic macular hypomelanosis of the melanodermic halfcast of Gullet-Hélénon, Bulletin de la Société de pathologie Exotique, 1997; 90: 333-334,

[19]. Kumanrasinghe SP, Tan SH, Thng S, Thamboo TP, Linag S, Lee YS. Progressive macular hypomelanosis in Singapore: A Clinicopathological study.Int. J. dermatol.2006; 45 (6):737-742

[20]. Duarte I, Della Nina BI, Goediano MC, Buense R, Lazzarini R. Progressive macular hypomelanosis: an epidemiological study therapeutic response to phototherapy. An Bras Dermatol. 2010; 85 (5): 621-624 